\title{
Kernos
}

Revue internationale et pluridisciplinaire de religion grecque antique

$6 \mid 1993$

Varia

\section{Religion and Magic}

\section{Manuel García Teijeiro}

\section{OpenEdition \\ Journals}

\section{Electronic version}

URL: https://journals.openedition.org/kernos/542

DOI: 10.4000/kernos.542

ISSN: 2034-7871

\section{Publisher}

Centre international d'étude de la religion grecque antique

\section{Printed version}

Date of publication: 1 January 1993

Number of pages: 123-138

ISSN: 0776-3824

Electronic reference

Manuel García Teijeiro, "Religion and Magic", Kernos [Online], 6 | 1993, Online since 07 April 2011, connection on 21 September 2021. URL: http://journals.openedition.org/kernos/542 ; DOI: https:// doi.org/10.4000/kernos.542 
Kernos, 6 (1993), p. 123-138.

\section{RELIGION AND MAGIC}

We all have an approximate idea of what magic is, and we use this name to refer to certain practices and rites which aspire to attain certain goals beyond our understanding. If we try to define magic scientifically, however, we meet with great difficulties. Many definitions have been proposed, but none has generally been accepted because none is satisfactory when confronted with actual facts: that is to say, when we go from theory to practice. It is easily demonstrable that many facts which we consider as magic go beyond the limits imposed by any such definition, whereas implicitly included in a definition are many elements which are not magic.

The problem has become an every day occurrence in the specialized bibliography. In fact, those working on documents, beliefs and magic acts, tend to avoid giving a general definition: they are convinced that no adequate definition can be found.

This is understandable. Firstly, one would have to distinguish carefully whether we are trying to define what we understand as magic, in the period in which we are doing our research, or trying to define what was understood as such in the period of the documents being studied. So, the concept of magic has a doubly subjective nature, because the relation of causality which exists between an action and an effect may be judged very differently in different periods and places, and by different people.

For us, for example, there is nothing magic in talking by telephone to someone who is absent, or in watching distant events on television. But when these inventions were introduced into some Arab countries, verses had to be read from the Koran to convince the more traditional that this was not a Shaitan diabolic trick. In contrast, we consider it to be a magic trick to try to see what is happenning elsewhere by looking in a mirror, in a crystal ball or in a bowl of liquid. However, a medieval manuscript ${ }^{1}$ explains this as a natural phenomenon: the sun functions

1 Val. Rose, Verzeichnis der lateinischen Handschriften der Kön. Bibliothek zu Berlin, Berlin, 1905, II 3, p. 1181, n 956, f. 21 v. Mentioned by L. DELATTE, La catoptromancie grecque et ses dérivés, Liège-Paris, 1932, p. 21 and n. 1, who makes reference to a previous quotation by L. THORNDYke, A History of Magic 
as an enormous mirror where everything is reflected, and one can pick up these images by reflecting solar light with a sheet of shiny metal over a liquid surface. This is how the famous Artefius (who was accepted as being the very Apollonius of Tyana ${ }^{2}$ ) obtained his visions in three receptacles filled respectively with water, oil and wine.

In ancient alchemy and medicine books we find many formulae which nowadays we consider to be magic, but which in their day would not have been called such, since they are based on suppositions which were then considered scientific. In actual fact, the doctrine of universal harmony, and man as a micro-cosmos, could lend theoretical justification to the whole of magic. The neoplatonists, above all, greatly exerted themselves in this direction.

Bearing in mind what has been said, a definition of magic can be proposed: magic is any action which tries to achieve an effect which cannot be explained by the normal law of causality. It must be borne in mind that this lack of an explanation is subjective and depends on the point of view adopted: it may be that of the magician, that of the client, that which dominates an epoch or corresponds to present knowledge.

With this definition we have done no more than trace, for better or worse, the common border between science and magic. there is another neighbouring area, the border with which it is just as difficult, if not more so, to establish, and that is religion.

The believer can expect that the divinity will help him in specific moments, over and above natural laws; that is, he can expect and ask for a miracle to be performed. If we wish to refer to Greek antiquity, we need look no further than the accounts which the iamata of Epidaurus have preserved (cf. the "miracles" of Isis and Serapis). The magician also tries to produce miracles with his magic, but here the difference is fundamentally one of tone and sentiment. When one prays to a god, one asks for something which depends on his will and which can be graciously conceded; when a magic rite is performed, one demands of the power invoked that it acts in a certain manner. Religion, moreover, is much more than the act of prayer and supplication, since it touches on all the fundamental aspects of human life; magic, in contrast, deals

and Experimental Science during the First Thirteen Centuries of our Era I, New York, 1923, p. 774. It is a Latin manuscript from the twelfth century.

2 According to the followers of Artefius himself and of his admirer Roger Bacon. See the note of DELATTE, op. cit., p. 19, 2. 
with specific issues and tries to satisfy the magician's, or his client's, specific desires ${ }^{3}$. A peculiar egoism, which manifests itself clearly in the requests made, is characteristic of magic spells. So, in the formulae which are found in the papyri and in the defixiones, in order to gain the love of another person, man or woman, not only do they desire that the person falls in love with another against his or her will, but also that they are unable to be at peace, are consumed with love for the magician and pursue him. In the legal defixiones the writer does not only desire to win the case against his opponents, but also that their tongues stick to their palate (that it turns around in their mouth, $\dot{\alpha} \pi \varepsilon \sigma \tau \rho \alpha \mu \mu \varepsilon v \eta$, as the lead tablets graphically say), etc.

By an abstract process we can specify, up to a certain point, our notions about science, magic and religion. This is useful for discussion, because scientific knowledge needs to define and to classify; however, these definitions do not always correspond to realities which are found in an isolated, pure form in specific cases which the texts confront us with. In the ancient and medieval world mixtures are normally found, forming complexes whose elements have to be analysed carefully.

Currently there is a clear tendency for those whom we might consider the heirs of the ancient magicians to lay claim to scientific status for their activities. Furthermore, an alternative nomenclature has emerged which bases its names upon combinations of Greek words. Amongst the jargon we are now well familiar with are parapsychology, telekinetics, telepathy and psychophony, to which some others, such as the strange hybrid ufology, have recently been added. The prestige offered by the so-called "officially accepted science" imposes this external imitation on those who fear being classed as charlatans and tricksters.

Up to the XVIIIth century, however, the greatest threat was that of being accused of witchcraft, which could result in being burnt alive. Ancient magicians had frequent recourse to necromancy, especially to those dead prematurely, the öwpor, and those who had suffered a violent death, the $\beta_{\imath \alpha \iota} 0 \theta \alpha v \alpha \tau o$, such as gladiators ${ }^{4}$; but even at this time a

3 See AF. SEgal, Hellenistic Magic: Some Questions of Definition, in Studies in Gnosticism and Hellenistic Religion Presented to Gilles Quispel on the Occasion of his 65th Birthday, Leiden, 1981, p. 350, with further literature.

4 See Th. HOPFNER, Griechisch-ägyptischer Offenbarungszauber I, Leipzig, 1921 [Amsterdam, 1974], § 251, 352, 784. 
demonizing process can be observed that concurred with the new philosophical and religious viewpoints of the epoch. This process was to last throughout the Middle Ages. A direct consequence of the introduction of Christianity was that the power who assisted the necromancer was regarded as being the devil or a demon as, at that time, belief in the existence of a whole host of such beings arranged hierarchically was widespread. It is also noteworthy that to have anything to do with the devil was, at that period in time, most severely punished. We can therefore understand why wizards tried their utmost to hide their activities under the pretence of feigned piety, as a result of which magic bore a great resemblance to religion.

Greek papyri frequently prescribe the observance on the part of the operator of certain conditions of ritual purity, such as abstaining from sexual intercourse or certain kinds of foodstuffs, or the wearing of certain clothing 5 . Byzantine magic and the magic of medieval Europe also add further obligations such as fasting, confession and the consecration of magic instruments. It could thus be maintained in their defence that those intervening were not in fact demons but rather angels acting with God's consent. An extreme form of such behaviour is, according to a XVth century witness, the case of priests who used their churches' patens to obtain visions which they in turn asked, through the intermediary of a child, all they wished to know.

Facts show, however, that such facades, even if sometimes they could be adopted in good faith, did not succeed in throwing wizards' and witches' enemies off the trail. In this instance we will highlight only two cases.

The first is that of the aforementioned case regarding the use of holy patens in catoptromancy experiments. J. Hartlieb, in his work on the forbidden $\operatorname{arts}^{6}$, written in 1456 and dedicated to John the Alchemist, eldest son of Frederick II prince elector of Brandenburgh, makes the point $^{7}$ that the diviners unwittingly bring about their own downfall

5 See A. Авт, Die Apologie des Apuleius von Madaura und die antike Zauberei, Giessen, 1908, p. 111.

6 Buch aller verbotenen Kunst, Unglaubens und der Zauberei. The note referring to patens appears in chapter XCIV. DELATTE, op. cit., p. 49 sq., calls attention to the value of this work and translates some of its chapters, amongst which (p. 55) is the aforementioned.

7 Chapter LXXXV (cf. the preceeding two). DELATTE, op. cit., p. 50 sq. 
because they mutter mysterious words in the ear of the child being employed in their magic sessions. One should be extremely wary of such words on the ground that "one cannot discover their meaning. One such word is Ragel. Throughout much of my life I have endeavoured to find out the meaning of such sounds. I have spoken to all sorts of people including Jews who as it turned out have no knowledge of them. Having asked Greeks, Tartars, Turks and in turn their astrologers and physicians, I have been totally unable to establish the meaning of such words. In my opinion it is to be feared that such words may in fact form a bond or pact with demons".

The second testimony we wish to mention is some one and a half centuries more recent than the first, in that it dates from the beginning of the XVIIth century. The subject is a somewhat bizarre autobiography of a Spanish soldier, Jerónimo de Pasamonte ${ }^{8}$. Having seen action in Lepanto and the capture of Tunis he was later taken captive by the Turks and held in the Near East for many years. On being rescued he returned home with the obsession that the world was filled with witches, wizards and sorcerers who were out to get him first and foremost. Convinced that all the ills of Christendom stemmed from dealings with the devil and the pacts with demons that are often made unawares, he dedicates his autobiography to the General of the Dominican order of preaching friars and to the Spanish assistant of the Father-General of the Jesuits at Rome. In his dedication to the latter he says:

For during the time I spent in the midst of Turks, Moors, Jews and Greeks I saw their undoing as a result of their dealings with fallen angels, whereas since I have been once more in the midst of Catholics I have been the object of numerous persecutions through evil craft, so that if I am alive today it is due only to the vast goodness of God. I have furthermore come to the conclusion that the downfall of all Christendom is due solely to having paid heed to evil spirits. I am furthermore of the belief that -and I would urge all to believe me in this-God will let the world have its own way until such time as all Catholics let themselves be lead by fallen angels, at which point the Antichrist would appear publicly given that hidden ones abound.

Contrary to other such autobiographies of the time by Captain Alonso de Contreras, Don Diego Duque de Estrada, Don Miguel de Castro, in which heroic challenges and duels abound, Pasamonte's work is filled

8 Printed in vol. XC of the Biblioteca de Autores Españoles, dedicated to XVIIth century autobiographies of Spanish soldiers, Madrid, 1956, p. 5-73. J. $\mathrm{M}^{\mathrm{a}}$. de Cossio's preliminary study does not give due credit to this interesting autobiography. 
with visions and life-saving revelations. At the end of one section of his work he quotes the Apostolic judgement: "Nolite omni spiritui credere sed probate spiritus si a deo sunt", at which point he once more insists on his denunciation of all who have dealings with fallen angels, making them appear as holy messengers from God. Such is the emphasis laid upon this idea throughout the work that it earned him a serious crossquestioning and detainment by the Inquisition, which finally vindicated his work.

It is also known that in the world of the Greeks and Romans magic also was reproached by science and religion. The hippocratic treatise On sacred disease already contains a far reaching criticism of the credibility of all who use this term when referring to epilepsy, and who furthermore resort to absurd remedies such as all manner of purification and sorcery; they advise against the wearing of black clothes and the crossing of hands or feet. They are like the magicians, sorcerers or charlatans who claim to be able to make the moon wane, cause eclipses of the sun, produce storms or fair weather, rain or drought, succeed in making water to spring from the earth, or indeed cause it to be sterile ${ }^{9}$. This is an important passage in that it shows that many of the magicians' claims found in the third and fourth century papyri are considerably older.

If we were to study the verdicts expressed by Plato and other Greek authors on magic we would find hesitation, little agreement and a tendency to distinguish between usefull and evil magic, a dichotomy not dissimilar to the present day distinction between black and white magic. On occasion we are faced with a general theoretic standpoint such as Pliny the Elder, NH XXVIII 10-29, where the question Polleantur aliquid verba et incantamenta carminum? is dealt with in the context of the cures and solutions man can get from himself. Despite some reservations a favourable conclusion is reached ${ }^{10}$. The most important work in this field is, of course, De Mysteriis Aegyptiorum by Iamblichus, a reply, as if it was the answer of the priest Abammon, to the problem that Porphyry had outlined in his Letter to Anebo on the validity

9 De morbo sacro, 2-4.

10 See Th. KöVER-ZulaUf, Reden und Schweigen. Römische Religion bei Plinius Maior, München, 1972, and Änne BÄUMER, Die Macht des Wortes in Religion und Magie (Plinius, Naturalis Historia 28, 4-29), in Hermes, 112 (1984), p. 8489. 
of the theory. It could be said that the De Mysteriis is really a theoretical justification of magic in a general philosophical context in which science and religion also play a part.

Besides discussion and controversy, there were also many persecutions. In Demosthenes' Athens an accusation of witchcraft could be punished by the death of the guilty and his family, as happened to a certain Theoris of Lemnos ${ }^{11}$. As is commonly known, Roman law has many repressive measures against witchcraft ranging from The Twelve Tables to Theodosius and Justinian's Codes. At first, attacks were made against agressive magic, but later all forms of sorcery and divination were prohibited. Burning of books, such as the Ephesus incident told in Acts, was a normal part of such persecutions, which were clearly politically motivated (to maintain moral order, for repression of the effective propaganda which oracles constituted, to avoid speculation on the death of emperors, etc.). The adoption of Christianity as official religion provided a real religious justification.

Given this state of affairs, it is fair to speculate on whether ancient magic did not also adopt disguises such as seeking safety under the mask of religion and science to avoid suspicion of impiety, as in the aforementioned case of medieval wizards ${ }^{12}$.

It is probable that this was indeed the case. Reference has already been made to Iamblichus' De Mysteriis, although the justification offered there is principally philosophical. Previously, in the second century, we have the testimony of Apuleius' Apologia. As is commonly known, the author of The Golden Ass was accused of having managed to marry a rich widow by means of magic arts. In his defensive speech, he systematically rejects one by one the theses of his accusers, but on reaching the heart of the matter -the accusation of practising magic- he digresses into an examination of the reality of magic, to which he

11 Dem., XXV, $79 \mathrm{sq}$. The accusation may have taken the form of a trial for

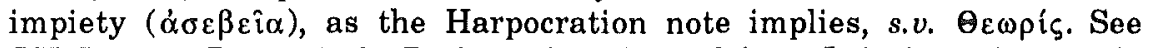
J.H. LiPsIUs, Das attische Recht und Rechtsverfahren, Leipzig, 1908, p. 365, with other references.

12 Cf. Fr. CUMONT, Les religions orientales dans le paganisme romain, Paris, 1929 , p. 143-146, regarding the change in meaning with which the commandments for ritual purity were carried out in Egypt. On p. 266 sq. reference is made to how astrology books progressively eliminate all that could be pagan, to the extent that on occasion the names of mythic gods or heroes are written cryptically. The process of depuration, says Cumont, can be followed from manuscript to manuscript. 
dedicates his excursus (XXV 9-XXVII 4). The thrust of Apuleius' argument is that "magic" and "magician" both have two distinct meanings, one of which is true and dwells amongst the wise, and another which is common and is the tool of the unknowing. Strictly speaking, "magician" is a Persian word meaning "priest". Texts by Plato ${ }^{13}$ are quoted to establish that "magic" means $\theta \varepsilon \omega v v \varepsilon \rho \alpha \pi \varepsilon i \alpha$, and

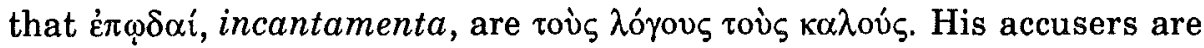
treacherous in that they used such words in the common meaning of being able to obtain anything by means of the irresistible force of charms. Had they really believed it, no such conflict would have arisen, or they would not have approached the trial without having adopted serious measures against such a formidable enemy. As it is always the case, the attack is carried out, merely out of ignorance, against philosophers and scientists who are very often labelled as impious and apostates. This was the case with Anaxagoras and with so many others. Religious people, too, come frequently under attack when they study the providence that governs the world. These are truly devout people who are accused of being "magicians", in accordance with the vulgar connotation of the term, as was the case with Epimenides, Orpheus, Pythagoras, Ostanes, Empedocles' Purifications, Socrates' daemon and Plato's tò $\alpha \gamma \alpha \theta$ óv.

As is apparent, Apuleius juggles in masterly fashion with the definition of "magician" and "magic" by resorting to the etymological meaning of the two words to lay claim to their rightful scientific and religious honours. It is, however, more interesting to note the lengths to which he goes to avoid labelling himself "magician" and to provide a convincing explanation of the criteria upon which these accusations are based. In effect what he says is that the true meaning of the word "magician" is a noble title, but he is nevertheless most definitely not a magician according to either definition. Too much was at stake in the trial to indulge in any such whim.

In his excellent commentary to the Apologia, Abt ${ }^{14}$ assembles passages from the magic papyri bearing similar expressions to those used by Apuleius. The founder of magic is a god, Hermes-Thot; both

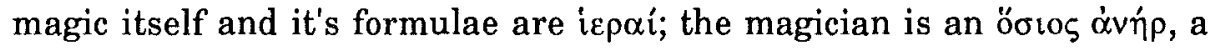
vir divinus, a $\mu v \dot{\sigma} \tau \zeta$, one who has been initiated to the mysteries, a

13 Alcibiades I, 121e and Charmides, 157a.

14 Op. cit. (see above n. 5), p. 108-115. 
$\mu v \sigma \tau \alpha \gamma \omega \gamma$ ós, who undergoes in his practices the strict conditions of ritual purity. Furthermore, Greek magic documents are known to contain on occasions signs of a peculiar religious nature, above all in the hymns that are found interspersed amongst the spells ${ }^{15}$.

In such instances it is impossible to determine to what extent such cases are mere mechanical syncretisms, in which gnostic and hermetic ideas interweave, and to what extent they exhibit true religious feelings in accordance with the ancient tradition of priest-magicians, or alternatively whether deliberate use of pious elements with a view to disguise can be established. It is well known, for instance, that Nilsson proposed that such hymns as are discovered in a state of defacement in the magic papyri are transpositions from hellenistic religious literature ${ }^{16}$. The papyri frequently point out that their contents must be kept secret, and two of them, LVII and LXXII, are written in code; but even in these instances we cannot be certain that these measures are taken through a wish to protect a piece of knowledge which by its very nature, must not be for public consumption, or whether protection is sought against censorship and persecution.

We can, however, be sure that the threat of persecution was a very real one, so much so that no work of Greek or Roman magic has reached us through tradition: they all perished in the aforementioned requisition and burning of books. As a direct consequence of this, it was not until the last century that anything was known other than what is to be found in literature, occasional imitations, such as Theocritus' second idyll, allusions and polemic.

Nowadays, however, we possess a fair number of documents, which is continually increasing, as a result of excavations: amulets, evil inscriptions, especially on lead, and, in a very special sort of way, the magic papyri themselves. The defixiones go right the way from the sixth century to Byzantine times and can be found throughout the ancient world. Greek magic papyri stem almost exclusively from Egypt, and are generally dated from the third or fourth centuries A.D. The briefest on occasion contain practical applications of sorcery to attain a set goal;

15 See A.D. Nock, Greek Magical Papyri, in JEA, 15 (1929), p. 230-232 ? = Essays on Religion and the Ancient World I, Oxford, 1972, p. 190-194).

16 M.P. Nilsson, Die Religion in den griechischen Zauberpapyri, in Bull. Soc. Royale des Lettres de Lund (1947-1948), p. 59-93 (= Opuscula Selecta III, Lund, 1960, p. 129-166). 
the most lengthy are fragments of ancient manuals on magic, most likely copies used by the magicians as books of spells, in that they leave blanks containing a simple abbreviation in the space where the names of the people on whom the spell is to be cast must be added. There are interesting examples of how the instructions outlined in these manuals were put into practice ${ }^{17}$.

Those documents do not of course contain pure magic. As has already been pointed out, various other elements are also to be found there amongst which are ones containing clear religious inspiration. An analysis of the contents could be made in which we could endeavour to separate the various component parts. We can, for example, compare the petitions to the divinity made by the magician with the prayers found in Greek and Roman literature in order to determine the areas in which they concur and those in which they differ.

The captatio benevolentiae on the divinity is a normal constituent part of prayer where a form of reminder is enacted of all that the faithful person has done in the God's service. "Should I on any occasion have performed such or such thing in your honour, likewise do the same for me". This outline can be extended by mentioning previous assistance from the power being called upon. It is indeed rare that threats are proferred, "should you not give me what I desire, I shall turn against you". When the do ut des appears in this form in a prayer there is normally an increase in the familiar tone which thus brings it closer in nature to beggars' importunate songs and folklore. Similarly in some of our own villages the statue of a saint who is unsuccessful in bringing rain is turned to face the wall, or alternatively, Arcadia's ritual practices which, as we know, inspired Theocritus' petition (VII 103-114) to the god Pan, where the latter is threatened with being whipped with stinging nettles and being made to endure extreme cold in winter and extreme heat in summer, if he does not give in to what is asked of him. Aristophanes parodied this aspect of the relationship that exists between man and the gods in his Birds, where the Olympians are obliged to accept a pact with Peisthetaerus and his fellows, who have founded a city in the clouds so that it prevented the smoke of the sacrifices from reaching heaven. Previously in Hipponax, fr. 32, the prayer to Hermes is parodied by means of an exact copy of the formulae of the professional petitioners with their characteristic diminutives, to minimize the

17 Cf. D. Grey Martinez, P. Mich. 6925: A New Magical Love Charm, unedited dissertation, University of Michigan, 1985. 
petition. In a Christian context an analogy can be made with the parable of the unjust judge and the imploring widow to show God that He will continually be importuned until $\mathrm{He}$ accedes to the request, as can be seen in one of the coptic Apothegmata patrum Aegyptiorum ${ }^{18}$ :

Abraham, disciple of the apa Djidjoi, was once tempted by the devil. The old man rose, raised his hands heavenward and exclaimed: Whether you wish it or not, I shall leave you no peace until he is healed. And he cured him immediately.

In magic, threats are commonplace and are to be found in the defixiones, in the talismans or in the papyri. The magician is of the belief that he has power over the beings he invokes thanks to his secret knowledge, and so he endeavours to frighten them. In a Leyden papyrus Persephone is threatened with having her flaming torches extinguished (PGM XII 1 ss.). In Paris' great magic papyrus a spell to obtain a demon's service concludes by offering him a sacrifice if he does as he is commanded; if he does not, he will receive an unbearable punishment ( $P M G$ IV 2095). Other instances show that the threat consists of revealing the divine mysteries or hidden actions or words, of not letting the gods pronounce their oracles, and of not helping the moon when it undergoes an eclipse ${ }^{19}$. In talismans, threats take on an averting evil character and adopt the pattern: "flee + name of the illness, evil or misfortune which is persecuting you or seeking you + name of some demon, god or beast, some being of a more powerful nature than the evil".

The value and efficiency of such threats, which also occur in Catholic exorcism rites against the devil, was long ago discussed among theological and philosophical circles of antiquity. It is known, for example, that this was one of the points under discussion in the controversy between Porphyry and Iamblichus ${ }^{20}$.

Partially associated with such threats is one of the peculiar provisions of the magic texts called $\delta \iota \alpha \beta \circ \lambda \eta$ in Greek: a name that corresponds to the concept of talking ill of someone in order to harm him

18 342, 9-12. Quoted from Fr. LexA, La magie dans l'Egypte antique, II, Paris, 1925, p. 214.

19 See Hopfner, OZ I, p. 493 sq.; S. Eitrem, Pap. Osl. I, p; 36; Fr. Pfister, "Drohung", in RAC; Nock, Essays I, p. 186 sq.

20 ProphyriUs, Epist. ad Aneb., 29. 
and also covers the semantic field of our nouns "slander" and "calumny"21.

There are instances in which the magician threatens to slander the god he is calling upon. Lucan was aware of this practice, in that when he tells how the Thessalian sorceress Ericto brings a corpse back to life in order that he may answer Sextus Pompeius' questions, she finds that life does not return with the alacrity she should wish, and sallies forth with formidable threats to the infernal gods, among whom is Persephone: the sorceress is going to reveal what she really ate in Hades when she remained there with the god of the dead, and also to reveal what had changed in her so that her mother would not wish to lay claim to her (VI 740).

It is more common, however that such slanders and calumnies should be aimed at the person who is to be harmed. If in instances such as the previous one we can perceive a manipulation of traditional mythology, this shows us how the ritual could be broken on occasion by very curious details.

What most draws our attention is that this procedure, the $\delta \iota \alpha \beta \circ \lambda \eta^{\prime}$ should be used in love magic to allow intervention of a supernatural power to assist the user in conquering the woman he desires. The lover tells the divinity -for example, the moon- that she makes sacrilegious offerings, slanders the goddess by saying that she has killed a man and drunk his blood, and committed other atrocities which the text takes pleasure in reporting. If one precisely exposes the $\delta\left\llcorner\alpha \beta \circ \lambda \eta^{\prime}\right.$ and carries out correctly the appropriate rites, one can be certain that the irritated divinity will remove the free will of the lady in question and will deliver her into the magician's hands.

"Having pronounced the spell and completed the offering, shout loudly and go down backwards" so says one text: "she will come straight away, but should the lover not immediately open the door to her, she shall die" (PGM IV 2492 sq.) 22.

Another peculiarity of spells can also be seen here: that of supposing that the gods or spirits invoked have the means to do whatever is asked of

21 S. EITREM, Die rituelle $\delta \_\beta \beta \lambda \eta ́$, in SO, 2 (1924), p. 43-61; ID., Pap. Osl. I, index s.v. "calumny"; ABT on Apul. Apol., p. 123 sq.

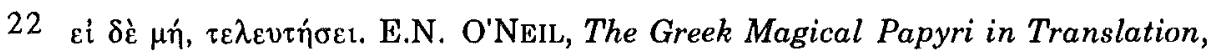
Chicago-London, 1986, understands "otherwise the spell will fail". 
them, while at the same time being easy to deceive, and are unable to distinguish between truth and falsity. The conflict between divine omniscience and the naïveté or ignorance they exhibit on certain occasions can already be seen in the poems of Homer, although it was not until much later that this was more explicitly outlined. In the third and fourth century A.D., the papyri show a theology that accepts a gobetween world of $\delta$ ífoves or "mediators", between the divinity and our earthly world. In reality, what we find in the spells of the latter part of the ancient world is the presumption that it is easy to deceive minor demons as it is the gods themselves. The same mentality is to be found in popular tales where all beings more powerful than man, giants, ogres, imps, witches, etc., can all be easily deceived whilst remaining wise and astute in other areas. Such is the case with Prometheus who, like his brother Epimetheus, owned names which had meaning for the Greeks and appeared in folk-tales, and was shown to have deceived Zeus over a sacrifice, as is told by Hesiod, Theog. $533 \mathrm{sq} .^{23}$.

The ease with which the powers called upon can be tricked is frequently combined with the idea that they can be easily frightened when the occasion calls for it, so that the magician most often resorts to this device to give force and authority to the formulae used through the

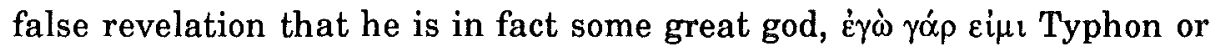
Seth, etc. ${ }^{24}$

Here we meet the point of the irresistible force that is in a true name. This is a very old belief, that is as present in the structure of ancient prayer as it is in magic songs. In both these instances a higher being is called upon and, to be sure that they are listening, those invoking them use not only the normal name but also epithets and phrases that define precisely all that is known of the god. Long series of appositional nouns and adjectives are thus formed, which are so characteristic of the hymns. When praying the aim is to attract the divinities' attention; when a curse is uttered, the goal is to impose an obligation on the divinity by means of the ineffable power of the true name. In practice, mixed forms are very common. Reference has already been made to the fact that the magic papyri intersperse amongst the magic spells large

23 Cf. CumonT, Rel. orient., p. 144: it is sufficient for the opening of the Aalu doors by Osiris that the soul knows the ritual formulae and denies its guiltiness. The soul is believed without more ado.

24 Cf. Fr. DoRnseIfF, Das Alphabet in Mystik und Magie, Leipzig, $1925^{2}$, p. 49. 
and on occasion perhaps complete fragments of hymns. This difficulty between ascertaining clearly what constitutes magic and what constitutes religion can be seen with great clarity in Finnish popular literature. In the Kalevala, for instance, the two extremes mix constantly. In this work, very clear examples can be found of the incomparable power given by knowledge. In this way when Väinämöinen, the hero, is injured by an axe, he is obliged to ascertain the origin of the iron in order to be cured ${ }^{25}$.

I know from whence it comes, it's first mother was the air, water it's elder brother, fire it's next and it itself was the youngest of all the brothers.

He continues with a lengthy explanation until everything is made clear, at which point a spell cures him. At the end of his song, however, it is to God that he gives thanks for having been cured. Elsewhere Pohjola's mistress sends a great cold against the heroes but they escape safe and sound because Lemmninkäinen knows all the details relative to the source of this cold ${ }^{26}$. Even now Finnish folklore contains spells of this nature to cure colic, tooth ache, sprained necks and even cancer ${ }^{27}$.

The secret knowledge he possesses is the key to the magician's power, but this must be exhibited in a very precise manner which generally tends to be oral. In other words, in the world of magic one of the fundamental elements is the irresistible force of words. It is important to point out that belief in the true word, and in the existence of formulae or spells which work on their own and interact with beings or natural forces against which they are directed, implies a way of thinking that in our terminology we could define thus: the relationship between the name and what is being named is, in the speech of most people at least, totally arbitrary, but the linguistic signs used by the magician are by no means whatsoever arbitrary. If we therefore investigate the nature of these true words, which are able to contain the very essence of the things themselves, we face two divergent traditions.

The first conceives such words as being totally different from those normally used by the humans. For us they are incomprehensible and are only known by wizards and sorcerers who, for that very reason,

25 Kalevala, IX 27 sq.

26 Kalevala, XXX 183 sq.

27 See K. KRонN, Magische Ursprungsrunen der Finner, Painettu Keravalla, 1924. 
gain power through this secret knowledge. They are, in fact, voices that resemble natural sounds such as the sighing of the wind or the gurgling of water, names made up through successions of vowels, alliterative formulae, real tongue-twisters, and palindromes that read the same backwards as forwards.

The second, on the other hand, works on a higher level. It maintains that the speech of the gods and the spirits is like our own, only more perfect, as names are no mere whim but do in fact offer an adequate definition of the nature of what is being named. This second viewpoint, which ties in with the meaningful names of folklore and dwells also in magic botanical or alchemy texts, gains precedence in literature. This is true not only for Greek. In fact there is a poem in the Icelandic $E d d a$ which tells of how a gnome bearing the name of "Know-it-all" had succeeded in making one of Thor's daughters take him as her fiancé during her father's absence. Upon his return, however, he is unwilling to accept his son-in-law, yet is unable to use force due to the formal promise made by his daughter. He resorts to trickery by demanding that the gnome undergoes a test to see if he knows as much as he is reputed to. At which point, a strange interrogation begins in which Thor asks the name of the earth, the heaven, the moon, the air and many other things in the languages of the gods, giants, elves and gnomes. The gnome answers promptly but through his own pride and folly he does not notice the coming of dawn and the first sunbeams turn him to stone.

It is clear that in this case we are facing a variation of the well known "duel of wits" wich is so common in folklore and mythology. The test can be analysed as follows: Thor, despite being a god, asks the names of things, himself using their ordinary names. "Know-it-all" answers "such a thing is called thus (repeating the word Thor had used in his question), using the speech of men, thus using the speech of Æsir, thus in the speech of Vanir, etc.". The choice of synonyms is determined by the alliterative rules which govern the beginning of strophes in the Icelandic poem. The same basic opposition remains throughout between the human names which are the words commonly used even in present day Icelandic or Norwegian languages, and the names belonging to the speech of other world's beings, which are synonyms of high poetic quality, or periphrases specifically created ad hoc. This can be seen in one of the stanzas. Thor asks "Know-it-all" using an almost invariable formula: "Tell me 'Know-it-all' the names of the night". The gnome answers: 
Night is called by men, and mist by the deities; mask say the great gods; no-light, the giants; the elves, joy-in-sleep; the dwarfs say knit-dreams 28 .

This may be compared, for example, with the first spell found in the magic papyri in Preisendanz' collection -an attempt to get a familiar

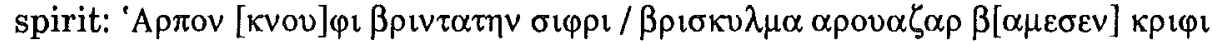
$v \imath \pi \tau 0 v \mu \imath \chi \mu \circ v \mu \alpha \omega \varphi) 29$.

The cultural atmosphere is very different, yet both the Icelandic poem and formula in the Greek papyrus are signs of the two concepts of aforementioned true word. To understand one well, we should be very aware of the presence of the other.

In order to understand religion correctly we must take magic into account, and vice versa. It is more profitable to analyse the characteristic components found in their concrete manifestations than to attempt general definitions, which are inevitably imprecise. This is the approach we have emphasized in this paper.

Departemento de Filología Clásica

Manuel GARCÍA TEIJEIRO

Facultad de Filosofía y Letras

Universidad de Valladolid

E - 47002 V ALLADOLID

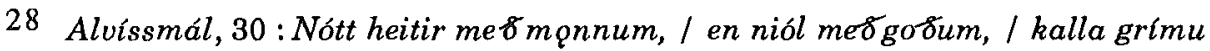
ginnregin, / óliós iǫtnar, / álfar svefngaman, / kalla dvergar draumniorun.

29 PGM I, 27 sq. (previously a series of the seven vowels). 